\title{
Publisher's note to "Commercial development of plant essential oils and their constituents as active ingredients in bioinsecticides"
}

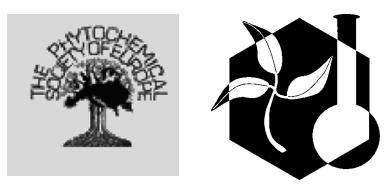

(C) Springer Nature B.V. 2020

The following article is a part of this Special Issue: EIAMNP 2018. It should have been included in this issue (Phytochemistry Reviews, Volume 19, Issue 3) instead of the previous issue (Phytochemistry Reviews, Volume 19, Issue 2).

- Isman MB (2020) Commercial development of plant essential oils and their constituents as active ingredients in bioinsecticides. Phytochem Rev 19: 235-241. https://doi.org/10.1007/s11101-01909653-9

Publisher's Note Springer Nature remains neutral with regard to jurisdictional claims in published maps and institutional affiliations. 